\title{
FONTES POTENCIAIS DE RISCO EM SALA DE OPERAÇŐES: IDENTIFICAÇÃO E AVALIAÇÃO
}

\author{
Maria Belén Salazar Posso:
}

\section{NOTA PRÉVIA}

POSSO, M.B.S. Fontes potenciais de risco em sala de operações: identificação e avaliação. Nota prévia. Rev. Esc. Enf. USP, São Paulo, 20(1):83-84, 1986.

Nossa atividade docente em Centro Cirúrgico permitiu observar alguns aspectos das condições de trabalho nesse ambiente, cuja problemática tem preocupado vários estudiosos. Tal problemática despertou nosso interesse, pois, parece interferir no desempenho profissional do pessoal que ali trabalha.

Não é raro encontrarmos, neste ambiente de trabalho poluído por gases anestésicos ou não, radiações ionizantes, ruídos excessivos, calor, frio, iluminação nem sempre favorável, além de outros fatores como insatisfação pessoal, duração da jornada de trabalho, remuneração nem sempre satisfatória e condizente com o tipo de atividade, necessidade de afirmação dentro desse contexto de relacionamento com os colegas; tudo isso pode ser fator responsável por sinais e sintomas relatados pelo pessoal que trabalha em sala de operações, ao término da jornada ou após anos de trabalho em condições insalubres.

Nem sempre essa sintomatologia é encadeada e correlata, porém, é motivo de frequientes queixas de cefaléia, irritabilidade, estafa, tédio, indiferença, perda da capacidade de concentração intelectual, instabilidade emocional, náuseas, vômitos, depressão e menor resistência às infeç̧ōes.

Preocupados com tais observações, surpreendemo-nos com o resultado de nossa reflexão: nós, enfermeiros, em todos esses anos temos permanentemente protegido nossos pacientes, aprimorando procedimentos que lhes dêem melhor assistência e maior conforto; assessorando autoridades na organização dos serviços hospitalares, de modo geral, e de enfermagem, em particular. E o que temos feito nós, no sentido de nossa proteção física e psíquica, na prática diária de nossa profissão?

Absorvido em seu trabalho, os enfermeiros muitas vezes têm-se esquecido de sua própria saúde. No entanto, ele tem o direito de

* Enfermeira. Assessora da Comissão de Organização do Departamento de Ensino do Hospital Albert Einstein. Professor Adjunto do Departamento de Enfermagem da Universidade de Taubaté. 
saber como trabalham, a que riscos estão expostos e a terem condições mínimas de segurança no trabalho.

Diante da escassez da literatura e da importância do assunto, sentimos a necessidade de identificar as fontes de risco de acidentes de trabalho e de doenças profissionais, existentes nas salas de operaçōes, e de avaliar o seu potencial.

POSSO, M.B.S. The risk sources in operating room: identification and evaluation. Preliminary note. Rev. Esc. Enf. USP, São Paulo, 20(1):83-84, 1986.

Our teaching activities in Operating Room enabled us to make some observations regarding environmental working conditions, an issue which has also been raised by several authors. This problematic matter has aroused our interest, since it seems to interfere with the professional performance of the personnel.

Not seldom we have perceived that such working environment, polluted by gases (anesthetic or not), ionizing radiations, excessive heat or cold, and in some cases inadequate illumination, added to other factors such as personnel dissatisfaction, working journey length, not always suitable or satisfactory earnings, desire of self-assurance within the social setting, an type of relationship among colleagues could be responsible for signs and symptoms referred by operating room personnel at the end of the journey or after years of work under these unhealthy conditions.

Symptoms not always enchained or correlated often motivate complaints such as headache, irritability, fatigue, boredom, indifference, loss of intellectual concentration ability, emotional instability, nausea, vomiting, depression and decreased resistance to infections.

Concerned with such observations, we became surprised with the results of our reflection. We, nurses, along all those years, have permanent and continuously protected our patients by ameliorating procedures for their best care and comfort; we have also given support to the authorities on matters related to hospital service organization in general, and in nursing in particular. And what have we been doing regarding our physical and mental protection in our daily work?

Absorved in their work, nurses very often neglect their own health. Nevertheless, they must be aware of their working conditions, as well as the risks they are exposed to. Moreover, they have the right to demand minimal safety conditions in their work.

In face of the scarce literature and the importance of the subject, we felt compelled to identify the risk sources of work accidents and professional diseases present in operating rooms, as well as to evaluate the potential risk to which individuals working in this environment are exposed. 